\title{
パーソナルエリアネットワークを実現する技術 Bluetooth
}

\author{
A Technology that Realize the Personal Area Network-Bluetooth-
}

\author{
酒井五雄 ${ }^{\dagger}$ \\ Itsuo Sakai
}

\section{StIIIIIA}

Bluetooth は $2.4 \mathrm{GHz}$ 帯域を使用する「パーソナルエリ アネットワーク」(後述)のための近距離無線規格で, 1998 年 4 月に $1 \mathrm{Mbit} / \mathrm{s}$ の伝送速度をもつ基本仕様が発表され た. 本論文では Bluetooth のハードウェア, ソフトウェア の基本構成及び動作を説明し，「だれでも手軽に使うこと を目指した無線規格」としての観点から，無線 LAN との 競合回避, 接続時間の短縮及び伝送速度高速化というこ れまでの仕様更新の要点に関して述べた後, 将来に向け た Bluetooth の動向を紹介する.

Iley woris

ユビキタス, Bluetooth, パーソナルエリアネットワーク ISM, UWB

\section{1.まえがき}

平成 16 年版情報通信白書の第 4 節「ユビキタスネット ワーク社会の実現と課題」の中で，「ユビキタスネット ワーク社会とは,『いつでも，どこでも，何でも，誰でも』 ネットワークにつながることにより，様々なサービスが 提供され，人々の生活をより豊かにする社会である」と 定義されている. 更に「ユビキタスネットワーク社会で は，ADSL，FTTH 等のブロードバンド回線，第 3 世 代携带電話, 無線 LAN，ブルートゥース(Bluetooth)等, ネットワークが多様化し, 端末においてもテレビ, 冷蔵 庫や洗濯機等の家電がネットワークにつながり，電子夕 グ等の小型チップが様々なものに付けられるなど多様化

†(株) ビーテーキュー, 東京都

BTQ Corporation, Tokyo, 110-0005 Japan
する」とも記述されている.

前述の白書で列挙されているネットワークの中で, Bluetooth は半径 10 メートル程度の比較的近距離の無 線通信を実現する技術である。また比較的近距離のネッ トワークは一般に「パーソナルエリアネットワーク (Personal Area Network)」と呼ばれ，この用途に使わ れる無線技術としてはBluetoothのほかにZigbeeが国 際標準規格として実用化されている。表 1 に「ローカル エリアネットワーク (Local Area Network)」用途とされ ている IEEE 802.11b/g 規格の無線 LANを加えた 3 方 式の概要比較を示す. Bluetoothの伝送速度はVer 1.1 で $1 \mathrm{Mbit} / \mathrm{s}$ であるが，後述する EDR モードなどで 2 Mbit/s，3 Mbit/sを実現する.

情報機器分野では IEEE802.11b 規格の無線 LAN が 1990 年代後半から事務所等の業務用途で使われている. 一方 1998 年 4 月に, Bluetooth と呼ばれる近距離無線技 術が発表され，翌年 7 月に仕様が一般公開された。仕様 策定当初から民生機器搭載を目的として, 低コストや低 消費電力を重視していたため, 情報機器や携带電話をは じめとする関係業界が注目した。

本論文では最初にBluetoothの要素技術について，次 いで技術的変遷の概要と今後の動向について述べる.

\section{Bluetooth のハードウェア，ソフトウェア技術}

\section{1 ハードウェア}

Bluetooth は最初から量産機器への搭載を目指してい るため, 高周波部を歩留り良く集積化できる周波数と出 力を選択することが低コスト化に重要であった。同時に 伝送速度を稼ぐためには高い周波数帯域での動作が求め られる。また広く民生機器に搭載されるためには無線局 免許の不要な带域が求められる。これらの条件を満足す る解として国際的に工業・科学・医療分野に割り当てら 
表 1 Bluetooth と他の無線方式の概要比較

\begin{tabular}{|c|c|c|c|}
\hline 項 目 & Bluetooth & ZigBee & $802.11 \mathrm{~b} / \mathrm{g}$ \\
\hline 主たる用途 & $\begin{array}{l}\text { デー夕通信 } \\
\text { 音声通信 }\end{array}$ & モニタリング制御 & 有線 LAN のコードレス化 \\
\hline 最大伝送速度 $(\mathrm{Mbit} / \mathrm{s})$ & $1,2,3$ & 0.25 & 11,54 \\
\hline 接続ノード数 & 7 & 64000 & 32 (推奨值) \\
\hline 伝送距離 $(\mathrm{m})$ & $\begin{array}{l}\text { Class } 1: 30 \sim 100 \\
\text { Class } 2: 3 \sim 10\end{array}$ & $30 \sim 100$ & $30 \sim 100$ \\
\hline 電池寿命 & 0 & (2) & $\triangle$ \\
\hline 搭載製品 & $\begin{array}{l}\text { 携帯電話 } \\
\text { ハンズフリー機器 } \\
\text { 携帯プレーヤ }\end{array}$ & $\begin{array}{l}\text { センサ } \\
\text { リモコン }\end{array}$ & $\begin{array}{l}\text { ノートパソコン } \\
\mathrm{PDA}\end{array}$ \\
\hline 規格名称 & IEEE802.15.1 & IEEE802.15.4 & $\begin{array}{l}\text { IEEE802.11b } \\
\text { IEEE802.11g }\end{array}$ \\
\hline
\end{tabular}

表 2 Bluetooth の主要緒元(Ver 1.1)

\begin{tabular}{|c|c|}
\hline 項 目 & 仕 様 \\
\hline 使用周波数 & $2.402 \sim 2.480 \mathrm{GHz}$ \\
\hline 空中線出力 & $\begin{array}{l}\text { Class } 1: 1 \mathrm{~mW} \text { 以下, } \\
\text { Class } 2: 1 \sim 4 \mathrm{~mW} \\
\text { Class } 3: 4 \sim 100 \mathrm{~mW}\end{array}$ \\
\hline 変調方式 & $\begin{array}{l}\text { 周波数ホッピングスペクトル拡散方式 } \\
\text { (一次変調 : } 2 \text { 值 FSK 方式) }\end{array}$ \\
\hline ホッピング速度 & 毎秒 1600 回 \\
\hline ホッピングチャネル & 79 チャネル $\quad(1 \mathrm{MHz}$ 間隔 $)$ \\
\hline 最大実効伝送速度 & $\begin{aligned} \text { 対称通信モード } & : 433.9 \mathrm{kbit} / \mathrm{s} \\
\text { 非対称通信モード } & 723.2 \mathrm{kbit} / \mathrm{s} \\
& +57.6 \mathrm{kbit} / \mathrm{s}\end{aligned}$ \\
\hline 個体識別 ID & 48 bit \\
\hline
\end{tabular}

れている $2.4 \mathrm{GHz}$ 带で, 集積回路外に終段パワーアンプ の付加が不要な出力 $1 \mathrm{~mW}$ という基本仕様が決められ た. Bluetoothの無線部の主要緒元を表 2 に示す。

無線部は $2.402 \mathrm{GHz}$ から $2.480 \mathrm{GHz}$ まで, $1 \mathrm{MHz}$ ス テップの 79 チャネルを用いる FH（周波数ホッピング） タイプの SS (スペクトル拡散)方式が採用されている.

この方式は，ある一定時間ごとに送受信の Bluetooth 機器間で，79 のチャネルをランダムに切り換えて通信 することにより，ある程度長い時間で見ると広い帯域に スペクトルを拡散できる。79チャネルの切換順序と夕 イミングが一致した送信装置と受信装置間で連続した データ伝送が可能となる。

Bluetoothでは毎秒 1600 回というこれまでに例を見 ない高速ホッピングが採用され，同じ周波数带域の他の システム，例えばホッピング周期が毎秒 50 回の FHSS 方式の無線 LAN 等との競合によるデー夕欠落を小規模 に分散させることができる。これにより，両者が同時 に使われても若干のパフォーマンス低下で使用が可能 となる。

また家庭などでは電子レンジが妨害源となる。電子レ
ンジは電源を半波整流した $50 \mathrm{~Hz}$ または $60 \mathrm{~Hz}$ の周期 で外部空間へわずかな電波が漏えいするとともに，加熱 対象物やその量によってスペクトルが変動する。このた め, 電子レンジを使っている近傍では特定のチャネルで のデータ転送は失敗するが, 誤り再送手法によってエ ラーフリー伝送を実現する。

変調は通常 2 段階で行われ，まず低い周波数でFSK (Frequency Shift Keying) 変調 (一次変調) を行う. FSK 変調方式とは搬送波 $f_{c}$ を中心に, 周波数偏差 $\Delta f$ を加え た $\left(f_{c}+\Delta f\right)$ を論理 $\left\lceil 1 」\right.$, 同じく減じた $\left(f_{c}-\Delta f\right)$ を論理 $\lceil 0 」$ と定義するものである，なお，変調速度は $1 \mathrm{bit} / \mu \mathrm{s}$ である. 次に, 可変周波数発振器で所定の出力周波数か ら $f_{c}$ を減じた第 2 搬送波を発生させ，これと一次変調 出力とを混合器を通して合成する (二次変調)，この可変 周波数発振器は, $625 \mu \mathrm{s}$ ごとに合成後の出力周波数が $2.402 \mathrm{GHz}$ から $2.480 \mathrm{GHz}$ の $1 \mathrm{MHz}$ ステップとなる周 波数をべースバンド処理部（後述）からの指示で発生す る. 空中線出力は標準タイプで $1 \mathrm{~mW}$ ，コードレス電話 親機のように据置機器用には高出力タイプとして送信出 力制御付きの $100 \mathrm{~mW}$ まで，更に $1 \mathrm{~mW}$ 未満の 3 クラ スが規定されている。これらの值は日本では無線局免許 及び無線従事者免許が不要ないわゆる特定小電力機器の 範囲内となっている。

実用使用範囲は標準タイプで半径 $10 \mathrm{~m}$ 程度を想定し ている。そして，最大実効伝送速度は対称通信モードで $433.9 \mathrm{kbit} / \mathrm{s}$, 非対称通信モードで $723.2 \mathrm{kbit} / \mathrm{s}$ と 57.6 $\mathrm{kbit} / \mathrm{s}$ である。また，音声伝送モードとして $64 \mathrm{kbit} / \mathrm{s}$ が規定されている。また, Bluetooth モジュールの個体 識別にはIEEE802で規定・管理されている MACアド レスが製造段階で組み込まれて ID（Identification）とし て用いられる。

Bluetooth は図 1 のように $2.4 \mathrm{GHz}$ 無線部, ベースバ ンド処理部, リンクマネージャの 3 機能ブロックから構 成されるモジュールが，高周波特性を管理されて供給さ 


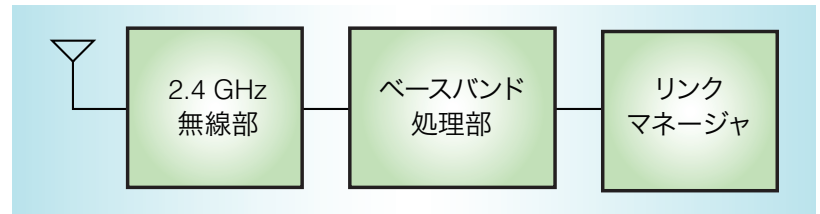

図 1 Bluetooth モジュール

れ, 多くの機器はこのようなモジュールを搭載している. 当初は無線部はアナログ IC, 他の 2 機能ブロックはソ フトウェアで処理するための MPU (Micro Processor Unit) ベースのセミカクタム IC，そしてプログラム格納 のための ROM の 3 チップで構成されていた， 2001 年 末あたりから $2.4 \mathrm{GHz}$ 無線部にも対応できるアナログ ディジタル混在プロセスでの量産化が主流となって, 1 個の IC と ROM（Read Only Memory）から構成される 小型化モジュールが一般化した。

\section{2 ピコネット (Piconet)}

電波という目に見えない通信路を不特定多数の機器で 有効に使うためには, 割当周波数内で互いに独立した複 数の通信路として多重利用する仕組みが必要となる. FHSS 方式ではホッピング周波数の切換順序とそのタイ ミングが一致することで 1 組の無線機器の通信路が形成 される. FHSS 方式で周波数帯域を多重化利用するため には, 複数のホッピングチャネル切換パターンを決めて, 干渉距離にある対向機器ペア間では異なる切換パターン を設定することが考えられる。しかしこれは固定設置機 器が主体の無線方式では許容できても, 携带情報機器と いう持ち運ばれるものへの搭載を目指す Bluetoothには 適さない.このため Bluetoothでは「ピコネット」と呼 ばれる独創的な手法で通信路を形成する仕組みを備え ている。

「ピコネット」では, 図 2 のような 1 台のマスタと 7 台 までのスレーブから構成される機器群が共通の通信路を 用いるネットワークとなる。電源投入後，すべての Bluetooth は「Standby (待機)」状態で定められたチャネ ルを受信している。ここである機器の Bluetooth がその 上位のシステムよりマスタとしての設定がなされると, 図 3 に示すようにマス夕は周囲の Bluetoothを探す 「Inquiry」動作を行う. 定められたパケット構造により, これを認識したBluetooth はマスタに対して自己の ID （固有アドレス）情報を送る。な执この際, 個々の Bluetooth は電源投入時からの内部クロックカウントを もとにして受信チャネルを決定している。このため, マ スタが送信チャネルを切り換えて「Inquiry」動作を繰り 返す際に, マスタの送信チャネルと待受け受信チャネル が一致したスレーブだけが, その送信チャネルに対応し た応答タイミングで応答する。このように受信チャネル を分散させることで, マス夕の呼びかけに複数のス

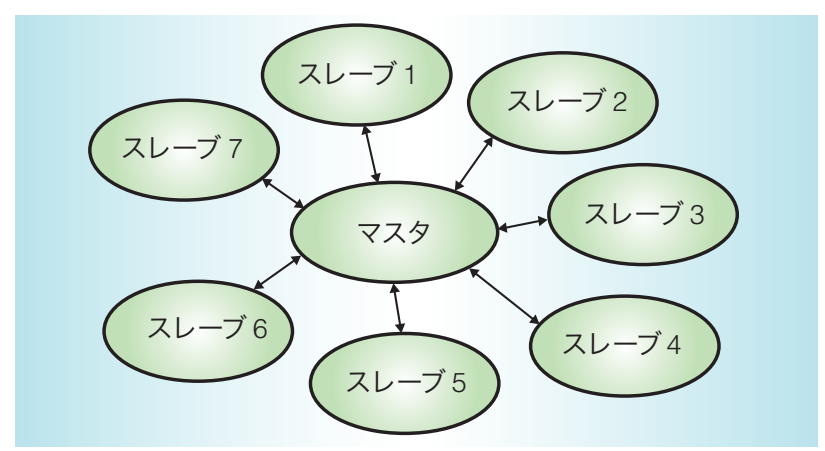

図 2 ピコネット

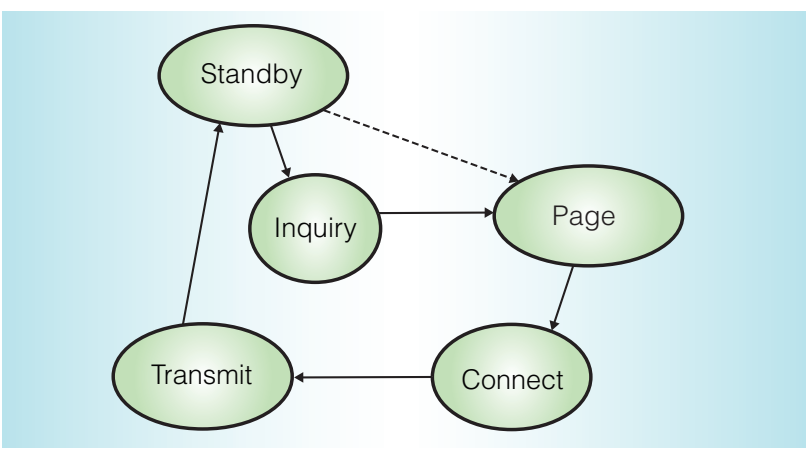

図 3 Bluetooth の状態遷移(マス夕側)

レーブの同時応答による電波の衝突発生を低減してい る. 更に同じ受信チャネルの複数の Bluetooth 機器がマ ス夕の呼びかけに応答する場合を想定して, それぞれ内 部で発生した乱数によって応答タイミングを遅延させる ことで, 衝突確率を低減する仕組みとなっている.

マス夕機器は一定時間このような「Inquiry（探索）」動 作を行ってリスト表示する。使用者はその中から接続す る機器を最大 7 台まで指定できる。このようにしてマス 夕機器は最大 7 台のスレーブ機器との間で「ピコネット」 を形成する、スレーブ機器は, マス夕機器からビーコン と呼ばれる信号を受信しており, 常に送受信に備えて内 部クロックをマスタ機器に同期させている. また, マス 夕機器の指示によってピコネットの状態を保持して低電 力待機モードに遷移させることができる． 3 種類の低電 力待機モードはどれも動作停止状態から内部夕イマで一 定期間ごとにビーコン及び復帰コマンドの受信動作のみ を行い, 自己への呼びかけがなければ再度動作停止状態 に戻ることを繰り返すもので, 受信復帰までの周期が長 い順に「Park」「Hold」「Sniff」が定義されている. 当然, 間欠的な受信動作が長いほど平均消費電力值は低くな る.このように 3 種類の低電力待機モードを規定するこ とで, マスタ機器側のアプリケーションプログラムに よって, 最も適した選択ができるように配虑されている。

\section{3 セキュリティ}

マス夕機器がピコネット上のスレーブ機器に対して通 信を最初に始める場合は, 「Page (呼出し)」モードに 
よって特定のスレーブ機器を指定する。このモードでは マス夕機器から乱数を送り，スレーブ機器はこれと自己 のID とを定められたアルゴリズムで演算する。こうし て得られた結果をマスタ機器に送り返し, 同時にマスタ 機器においても送信した乱数とリストに登録されたス レーブ機器 ID を用いて同じアルゴリズムで生成された 結果と照合してスレーブ機器の認証を行う。ここで重要 なのは，ID はユーザレベルでは書換えできないことと， 乱数や演算結果はアプリケーションなどの上位システム から読み取る，あるいは書き換えることができないため, 認証の安全性が確保されている点である。

この認証に成功すると「Connect（接続)」モードを経 て図 3 の状態遷移図の「Transmit（送信）」モードに移行 する。この際，伝送デー夕を保護するための暗号化伝送 もマスタ機器のアプリケーションによっては指定可能で ある。暗号鍵としてはマス夕機器から送られる 128 bit の初期コードと通信ごとの乱数及びスレーブ機器 ID を 定められたアルゴリズムで演算した結果を用いる。この 結果，個々のスレーブごとのみならず同じスレーブ機器 に対しても「Connect (接続)」を経るごとに新しい暗号 鍵が生成されて, デー夕のセキュリティを確保している。

「Transmit」モードでは図 4 に示すようにホッピング 周期 1600 回/秒の逆数である $625 \mu \mathrm{s}$ がフレームと呼ば れる基本単位となっている。前述のとおり，フレームご とに79チャネルのうち, 一つのチャネルが切り換えて 利用される。伝送内容は用途によって様々なため，図 4 に示す 1 フレーム/パケットの伝送パターンのほかに，3 フレーム/パケット， 5 フレーム/パケットの合計 3 種類 が定められている。表 1 の最大伝送速度及び表 2 の最大 実効伝送速度は 5 フレーム/パケットの場合に得られる。

パケット長は，長ければ長いほど伝送速度は向上する が，一方で誤り環境下では誤り検出によるパケット再送 頻度が高くなり，実効伝送速度が著しく低下する。この ため，マス夕側アプリケーションプログラムが常に伝送 品質を監視することによって，その状態で最も実効伝送 速度を高くできるパケット長に切り換えて使うのが効果 的である。

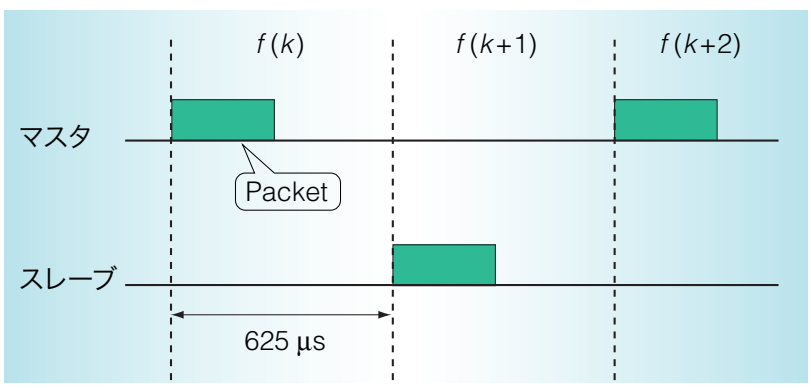

図 4 送信タイミング

\section{Bluetooth の変遷}

\subsection{AFH (Adaptive Frequency Hopping)}

IEEE 802.11b/g 規格の無線 LAN は Bluetooth と同じ 周波数带域に中心周波数 $2412 \mathrm{MHz}$ から $6 \mathrm{MHz}$ 間隔で 11 チャネル（日本では旧 ISM 带域と連結使用すれば 14 チャネル）を使用している。近くに設置された互いに独 立した無線 LAN 機器システムは, 最低 5 チャネル離れ たチャネルを使わないと，無線 LAN システム間での周 波数競合が発生する。一方初期の Bluetooth は無線 LAN との間で，すべての無線 LANチャネルにおいて 周波数競合が発生した。

そこで 2003 年 11 月に特定のチャネルを避けてホッピ ングする AFH (Adaptive Frequency Hopping) 機能を 盛り込んだ Bluetooth 仕様 V1.2 が発表された。

AFH は, Bluetoothの 79 ホッピングチャネルの特定 チャネルだけを使って通信を行う機能である。使用チャ ネル決定の具体例としては，使用者がマス夕機器側の ユーティリティに無線 LAN で使っている周波数または チャネルを入力することで，それを避けるように Bluetoothの使用チャネルを決める方法が製品化されて いる.

従来は $2402 \mathrm{MHz}$ から $2480 \mathrm{MHz}$ までの $1 \mathrm{MHz}$ おき の 79 チャネルを，仕様に基づいた擬似的にランダムな チャネル切換 (ホッピング)パターンで通信した。使用周 波数チャネルすなわちホッピングパターンは全帯域を均 一に利用するため，無線 LAN との周波数競合が起こっ て互いにパフォーマンスが下がることがあった。

仕様 V1.2の AFH機能によれば, 無線 LAN と Bluetooth 機器との周波数競合を避けることができる. 図 5 に AFH 動作させた Bluetooth の出力波形をスペク トルアナライザで測定した一例を示す。また図 6 に IEEE 802.11b 規格の無線 LAN の出力測定例を示す。ど ちらも横軸は中心周波数が $2.441 \mathrm{GHz}$ で表示間隔が 10 $\mathrm{MHz} / \mathrm{div}$ である。

図 5 の例では，空いているように見える中央部分は， 無線 LAN のためにホッピングを避けるようチャネル設 定して動作させている。図 6 と対比させて見れば，両者 の動作周波数が分離されているのが分かる.

使用を避けるチャネルが増加すると，Bluetoothが データ伝送に使うチャネルが減る。しかし, 周波数ホッ ピング方式のスペクトル拡散方式が成立するためにはあ る程度のチャネル数が必要である. Bluetoothでは最低 ホッピングチャネルを 20 としている.

図 7 に無線 LAN との周波数共用例を示す。無線 LAN を同一空間で最大限利用する場合，周波数競合を 避けるために無線 LAN チャネルを 1，6，11に設定す 


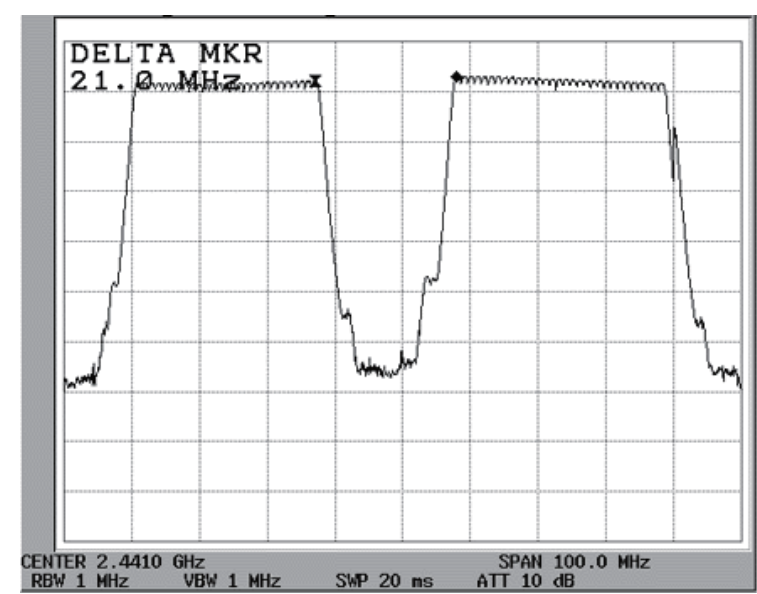

図 $5 \mathrm{AFH}$ 動作させた Bluetooth の出力

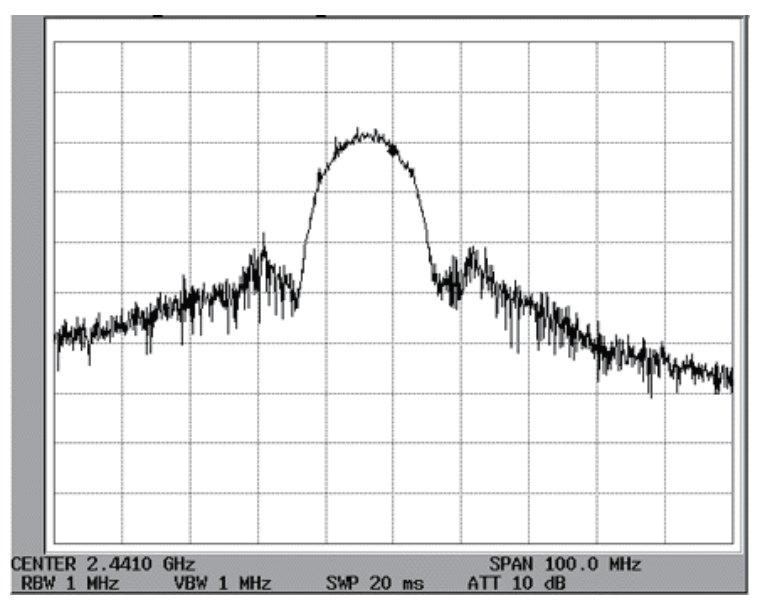

図 6 IEEE802.11b 規格の無線 LAN の出力

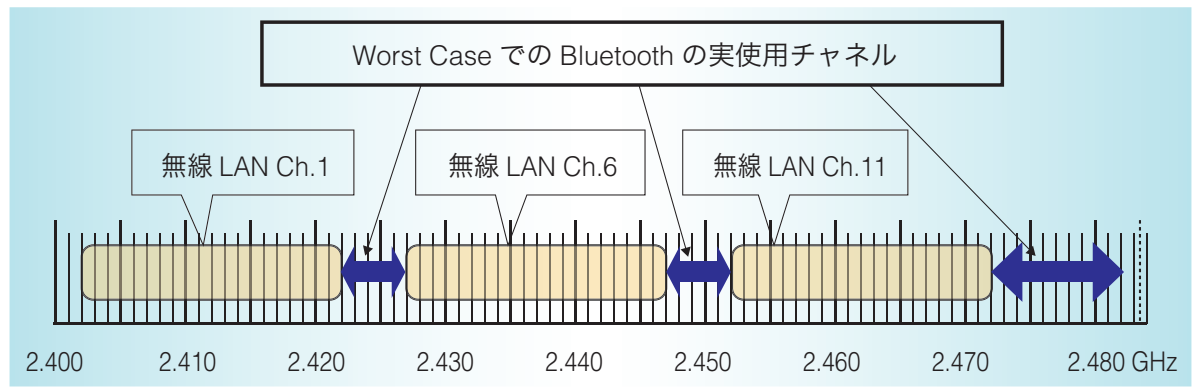

図 7 複数の無線 LAN システムと空き周波数領域

る必要がある（3 システム同時利用）。この場合，各無線 LAN チャネルの間, 及びチャネル 11 よりも高い周波数 帯域に未使用部分があり，これらの合計が約 20 チャネ ルとなる。

更にFCC247.15 及び欧州の EN300328 規格で周波数 ホッピング方式のスペクトル拡散方式の必要要件として 最低ホッピングチャネル数がそれぞれ 15,20 と定めら れていることから，両規格を満たす值として 20 が採用 されている。

\section{2 接続時間短縮機能}

\section{(1) First FHS}

Bluetooth 仕様 V1.1 以前では，最初に周りの Bluetooth 機器の存在を探索する「Inquiry」パケットを認識しても, その直後の応答スロットでは応答が保留されていた。こ れは多くの Bluetooth 機器の存在を想定し, 各機器が内 部で発生させた乱数に定数を掛けた時間後の応答スロッ トで応答することで，応答タイミングを分散させるのが ねらいであった。

しかし仕様 V1.2 では図 8 に示すように，最初の応答 スロットにも応答を許すことで，応答するBluetooth 機 器が少ない場合の応答時間短縮を図った。仮に複数の Bluetooth 機器が同時に応答して衝突しても, 各機器が 内部で発生させた乱数に定数を掛けた時間後の応答ス ロットへの応答を複数回繰り返す。したがって同じ条件

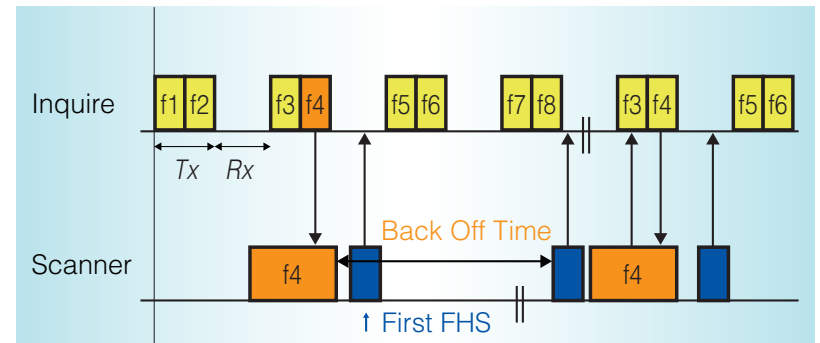

図 8 Inquiryへの応答タイミング

下では仕様 V1.1 以前の機器の接続時間より短縮され る.

（2）インタレースドスキャン

Bluetooth は Inquiry 過程では特定の 32 チャネルを使 うことが仕様で定められている。そして電源が投入され た Bluetooth 機器はその 32 チャネルのうち, 内部パラ メータから仕様に基づいて算出した特定の 1 チャネルで 間欠受信を行っている.

一方, Inquiryを行う Bluetooth 機器は仕様に基づい て 32 チャネルの並べ換え処理を行い, 並び順で前半 (A) と後半 $(\mathrm{B})$ の 2 群に分ける。そして仕様 V1.1 以前では, 図 9 のように 2.56 秒ごとに片方の群を繰り返し続けて 送出した。このため, たまたま $\mathrm{A}$ 群に属するチャネル で受信している Bluetooth 機器は最初の 2.56 秒の間に 検索パケットが受信できる。しかし反対に，B 群に属す 


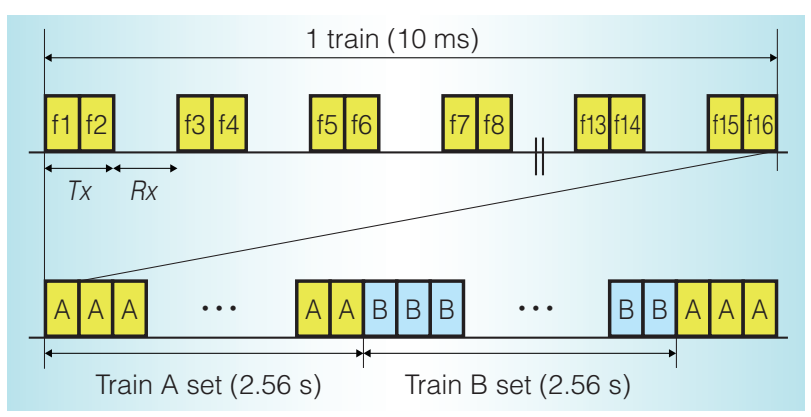

図 9 仕様 V1.1 以前のスキャン方式

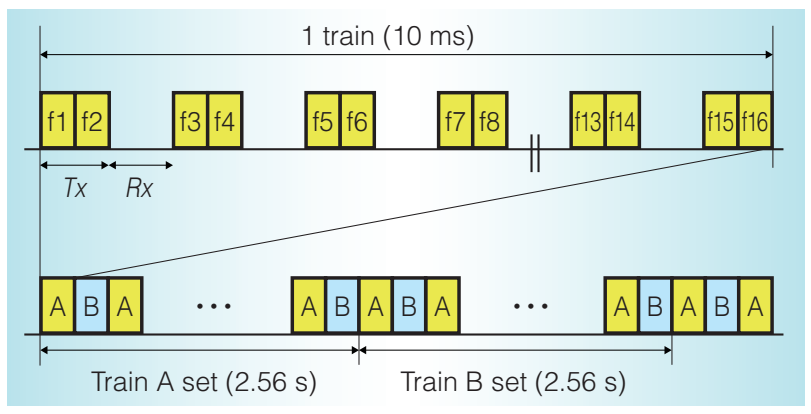

図 10 仕様 V1.2 のインタレースドスキャン

るチャネルで受信している Bluetooth 機器は最初の 2.56 秒の間には絶対に検索パケットを受信できない.

それに対して仕様 V1.2では図 10 に示すように A, B の 2 群のチャネルを交互に使用して検索パケットを送 る。このため $\mathrm{A}$ 群及び $\mathrm{B}$ 群のどのチャネルも最初の 2.56 秒で検索パケットの送出に使われる。したがってい かなる受信チャネルで待機している Bluetooth 機器でも 早い段階から待機チャネルでの検索パケットが送出され る.

ここで仕様 V1.1 の機器との接続高速化効果を考えて みる。 First FHS を「送出」できるのは仕様 V1.2 以降の Bluetooth 機器であるが, First FHS の「受信」は全仕様 で可能である。したがって探索側が仕様 V1.1 以前の機 種であっても応答側機器が仕様 V1.2 以降のものであれ ば，First FHS による応答及び接続の高速化の恩恵が受 けられる。一方インタレースドスキャンは送出側が仕様 V1.2でなければ対応できないが，受信側は仕様 V1.1 以 前のものでも恩恵が受けられる.

このように仕様 V1.2 の First FHS とインタレースド スキャンの両方を用いれば，送受どちらが旧仕様であっ ても応答及び接続高速化機能の一方の恩恵を受けること ができる。

\section{3 データ伝送速度の高速化}

(1) $\pi / 4$ シフト DQPSK による $2 \mathrm{Mbit} / \mathrm{s}$ 伝送モード かねてから Bluetooth のデー夕伝送速度の向上を望む 声は強かった。これにこたえて2004年11月に Bluetooth仕様 V2.0+EDR が発表された。EDRは

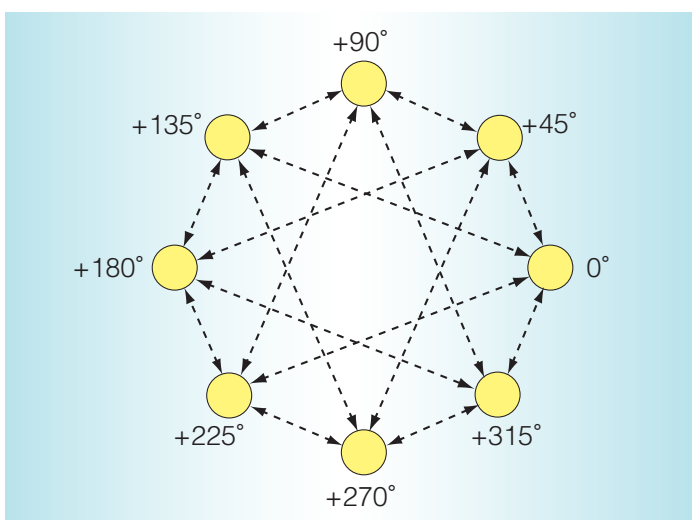

図 $11 \pi / 4$ シフト DQPSK 変調

Enhanced Data Rate の略で, V1.2 以前の仕様のデー夕 伝送速度 $1 \mathrm{Mbit} / \mathrm{s}$ を改善したことを意味するネーミン グである。

この伝送モードはこれまでの Bluetooth 仕様 V1.1, 及びV1.2 と接続互換性を保持している. そのため, 探索, 接続及びデータ送信パケットのヘッダ部分は従来と同じ 2 值 GFSK 方式で変調する。 あらかじめネゴシエーショ ン段階で互いにV2.0 + EDR 対応 Bluetooth と確認でき た場合には，ペイロードと呼ばれるデー夕通信ブロック だけを $\pi / 4$ シフト DQPSK 変調で送受信する。

$\pi / 4$ シフト DQPSK は 4 值の位相変調方式で, 図 11 に示すように位相偏移は土 $\pi / 4$ あるいは $3 \pi / 4$ とな る。また，図の中心部の矢印のように，位相が $\pi / 4 a$ ず れた 2 組の変復調ポイント $\left(0^{\circ}, 90^{\circ}, 180^{\circ}, 270^{\circ}\right)$ と $\left(45^{\circ}\right.$, $\left.135^{\circ}, 225^{\circ}, 315^{\circ}\right)$ を交互に使って $(0,0)$ から $(1,1)$ の 4 值 に対応させる。この複雑な手順の見返りに，単純な DQSPK に比べ，変調後及び復調前の増幅回路の直線性 など諸性能への要求が緩和される.

（2）D8PSKによる $3 \mathrm{Mbit} / \mathrm{s}$ 伝送モード

この伝送モードでも $2 \mathrm{Mbit} / \mathrm{s}$ 伝送モードと同様, ペ イロードと呼ばれるデータ通信ブロックだけを必要に応 じてD8PSK 変調で送受信することで，これまでの Bluetooth 仕様 V1.1 及びV1.2 と接続語互換性を保持し ている。この D8PSK は図 11 で示した 8 個の変調ポイ ントを $(0,0,0)$ から $(1,1,1)$ の 8 值に対応させる変調方 式である。

Bluetoothのロゴ認証規定で，仕様 V2.0 + EDRは $\pi / 4$ シフト DQPSKによる $2 \mathrm{Mbit} / \mathrm{s}$ 伝送モードのサ ポートは必須項目となっている。一方 8DPSKによる 3 $\mathrm{Mbit} / \mathrm{s}$ 伝送モードはオプション（任意）項目と規定され ている.

(3) 仕様 V2.0+EDRに向いた用途

$\pi / 4$ シフト DQPSK による $2 \mathrm{Mbit} / \mathrm{s}$ 伝送モード及び D8PSK による $3 \mathrm{Mbit} / \mathrm{s}$ 伝送モードは，今後の音声・音 楽応用製品で伝送品質の向上に寄与するものと期待され 


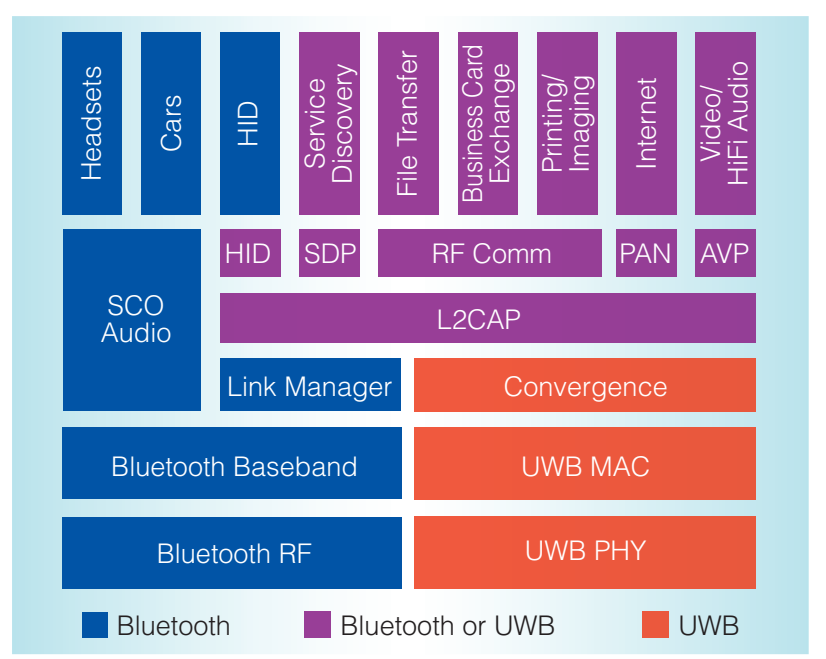

図 12 Bluetooth と UWB の融合概念図

ている。 もちろん通常のデー夕伝送でも, 伝送速度が速 いことがよいのはいうまでもない.

この伝送モードによって単位時間当りの伝送量が増加 するため, 携带電話と外部機器との間のマルチプロファ イル接続（例えば音声通話とデー夕通信または音楽伝送 の同時送受信)も可能となった.

\section{4. 今後の動向}

\subsection{Bluetooth と UWB との融合}

Bluetoothの技術面で今後期待されるのはUWB (Ultra-Wideband) とのコラボレーションである. 発表 された資料によると既存の Bluetooth の最下位層部分 に, Multiband-OFDM Alliance (MBOA) が推進してい る MB-OFDM (MultiBand Orthogonal Frequency Division Multiplexing) 方式の UWB 無線部を追加した 図 12 に示す構造となっている.

これによると, 従来仕様の Bluetooth 機器とは完全互 換を保ちつつ, UWB の下位層を有する Bluetooth 機器 間ではデー夕伝送量の比較的多い用途で, 既存の Bluetooth プロファイルをUWBにも使うことを目指し ていることが読み取れる。

Bluetooth SIG では, Bluetooth と MB-OFDM 方式の UWB との融合を実現するための技術的検討グループ で, 既存の仕様を最大限生かすことを念頭に置いて仕様 改定作業を行っている. Bluetooth と MB-OFDM 方式 のUWB との融合規格は Bluetooth V3.0 と名づけられ, 2007 年末に仕様書ドラフト版が公開される予定となっ ている.

\section{5.むす び}

本論文で Bluetooth の生い立ちから今後の動向を簡単
に紹介した，今日の主要な Bluetooth 機器の応用分野は 携带電話, 自動車搭載オーデイオ/ナビゲーションシス テムで, 既に身近な存在となっている。これは音声・音 楽伝送用途には現状の伝送速度で十分実用に供すること が可能なためである.

しかし今後は動画像伝送機器のワイヤレス化が期待さ れている. この要求は様々な無線規格に広く求められて いるが, BluetoothではUWB との融合で解決を図って いる. 1 日も早く Bluetooth V 3.0 仕様が完成し, それを 搭載した製品の実現が待たれる。

\section{文献}

［1］総務省(編), 平成 16 年版情報通信白書, July 2004 .

[2] Bluetooth SIG, "Bluetooth core specification V1.1," Nov. 2002.

[3] Bluetooth SIG, "Bluetooth profile specification V1.1," Nov. 2002

[4] Bluetooth SIG, "Bluetooth version 1.2 core specification, Volume 2," Nov. 2003

[5] Bluetooth SIG, "Qualification program reference document, Revision 1.0," Feb. 2002.

(平成 19 年 3 月 26 日受付, 6 月 5 日再受付)

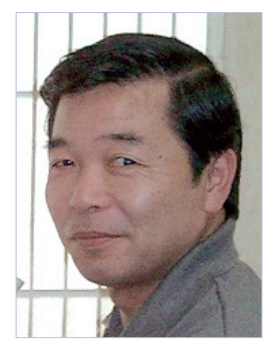

\section{酒井 五雄}

- 1976 名古屋大学大学院工学研究科電気 専攻修士課程了. 同年 (株) 東芝入社. パソ コン, 日本語ワードプロセッサ, PHS 内 蔵PDA 等の開発を経て現在 (株) ビーテー キューヘ出向中. 